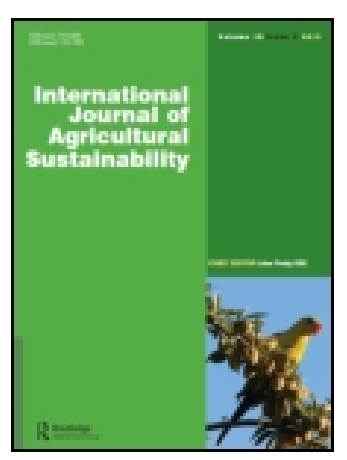

International Journal of Agricultural Sustainability

ISSN: 1473-5903 (Print) 1747-762X (Online) Journal homepage: http://www.tandfonline.com/loi/tags20

\title{
Optimizing dambo (seasonal wetland) cultivation for climate change adaptation and sustainable crop production in the smallholder farming areas of Zimbabwe
}

\author{
G. Nyamadzawo, M. Wuta, J. Nyamangara, P. Nyamugafata \& N. Chirinda
}

To cite this article: G. Nyamadzawo, M. Wuta, J. Nyamangara, P. Nyamugafata \& N. Chirinda (2015) Optimizing dambo (seasonal wetland) cultivation for climate change adaptation and sustainable crop production in the smallholder farming areas of Zimbabwe, International Journal of Agricultural Sustainability, 13:1, 23-39, DOI: 10.1080/14735903.2013.863450

To link to this article: http://dx.doi.org/10.1080/14735903.2013.863450

冓 Published online: 31 Jan 2014.

Submit your article to this journal ए

Цll Article views: 517

Q View related articles $₫$

View Crossmark data \lceil 


\title{
Optimizing dambo (seasonal wetland) cultivation for climate change adaptation and sustainable crop production in the smallholder farming areas of Zimbabwe
}

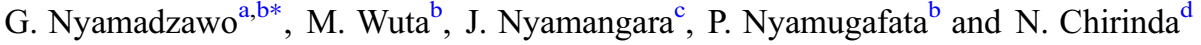 \\ ${ }^{a}$ Department of Environmental Science, Bindura University of Science Education, Box 1020, Bindura, \\ Zimbabwe; ${ }^{b}$ Department of Soil Science and Agricultural Engineering, University of Zimbabwe, Box \\ MP167, Mount Pleasant, Harare, Zimbabwe; ${ }^{c}$ International Crops Research Institute for the Semi Arid \\ Tropics (ICRISAT), Matopos Research Station, Box 776, Bulawayo, Zimbabwe; ${ }^{d}$ Department of \\ Agroecology, Aarhus University, Blichers Allé 20, DK-8830, Tjele, Denmark
}

\begin{abstract}
Most smallholder farming areas of Zimbabwe have low soil fertility and low rainfall, which has continually decreased over the past years. In recent years, most of the smallholder farming areas have experienced perennial droughts, poor rainfall distribution and crop failures and these have been attributed to climate change and variability. Cultivation of dambos, which are seasonal wetlands, presents a climate change and variability adaptation option for smallholder farmers. This synthesis analyses the role of dambo cultivation in climate change and variability adaptation and discusses future directions for sustainable dambo utilization. The data on current dambo farming practices were collected from literature, surveys and field observations. The results showed that farmers grow crops in dambos as an adaptive strategy to climate change and variability and have largely abandoned upland fields where yields are $<1 \mathrm{tha}^{-1}$ in preference of dambos where yields average $2-3 \mathrm{tha}^{-1}$. Dambo cultivation offers a buffer against crop failures and has resulted in improved household food security. We conclude that dambo cultivation is a potentially beneficial farmer-driven climate change and variability adaptation strategy. However, if not properly designed and managed, dambo cultivation may result in their degradation hence there is need for further research to evaluate options for sustainable dambo utilization as intensification of dambo agriculture is important for food security.
\end{abstract}

Keywords: climate change; dambos; cultivation; household food security; climate smart agriculture

\section{Introduction}

Food security in most smallholder farming systems of southern Africa mainly depends on rain-fed staple crop (cereal) production. The majority of smallholder farming areas in Zimbabwe are located in semi-arid areas where rainfall is low, erratic and unreliable (Department of Meterological Services 1981, Bratton 1987). Soils are relatively less fertile compared with sub-humid areas where intensive agriculture is concentrated. Of late, the incidence and extent of mid-season dry spells and late start and abrupt end of the rainy season have increased and have been attributed to climate change and variability. Most climate change models have projected a decrease in rainfall in southern Africa, including Zimbabwe (New et al. 2006) and this implies worsening drought-related food shortages. Decreasing rainfall is a major challenge as most of the agricultural

*Corresponding author. Email: gnyama@yahoo.com 
systems of southern Africa are predominantly rain-fed and irrigation systems are not well-developed (Camberlin et al. 2009).

Increased air temperatures and less reliable precipitation are associated with several agricultural stresses including increased crop water shortages, shorter crop growing periods in some areas, changes in plant and animal diseases, changes in pest distribution patterns and more generally, reduced suitability of some areas for agriculture (Branca et al. 2011). Parts of sub-Saharan Africa, where high vulnerability to weather shocks already exists, are expected to be hit the hardest, with predicted decrease in agricultural productivity of between $15 \%$ and $35 \%$ (Cline 2007, IPCC 2007). Climate change has resulted in increased frequency of crop failure and, consequently, increased food insecurity among smallholder farmers in Zimbabwe. In most developing countries, such as Zimbabwe, limited capacities to adapt to climate change have led to increased crop failure and severe food shortages. In light of the changing climatic patterns, one potential adaptation strategy that is used by smallholder farmers is the cultivation of dambos.

Dambos are seasonally saturated, grassy, gently sloping valley floors (Acres et al. 1985, Mäckel 1985, Boast 1990). Ivy (1981) defines dambos as

Land that is saturated to within $15 \mathrm{~cm}$ of the surface for the major part of a rainfall season of average or above average rainfall and which may exhibit one or more of the following characteristics: (i) the presence of mottles or rust-like stains in root channels within $15 \mathrm{~cm}$ of the surface. (ii) a black topsoil horizon very rich in organic matter $(\mathrm{OM})$ overlying pale leached sands; (iii) a dark grey or black heavy clay showing considerable surface cracking when dry.

Dambos cover an estimated $20 \%$ of the gently undulating land surface on the elevated plateaus of central and southern Africa (Bullock 1992) and in Zimbabwe dambos occupy an estimated 1.28 million hectares (ha) (Whitlow 1985). An estimated 12\% (0.26 million ha) of dambos are in the smallholder farming sector, while 78\% (1.02 million ha) are in the former large-scale commercial farming areas (Whitlow 1984) which have since been subdivided into model A1 and A2 farms under land reform programme (Scoones et al. 2010).

The cultivation of dambos is widespread in the southern Africa region and has been reported in other African countries such as Malawi (Mloza-Banda 2005, Chadanti-Malunga 2011) and Zambia (Shimada 1994, Kuntashula et al. 2006). In Zimbabwe, the cultivation of dambos in the smallholder farming sector was reported nearly a century ago by several authors (Brown 1899, Selous 1920, Jollie 1924, Russell 1971, Whitlow 1985, Bell and Roberts 1991, Scoones and Cousins 1991). Palmer (1977) reported the growing of maize and other indigenous grains in the 1860s, while Brown (1899) reported that 'the most fertile portions of the lands were the open, marsh glades, called vleis, near small streams which the "natives" utilize to raising excellent quality rice'. In 1925, the Native Commissioner for Chiota wrote that he was pleased 'to note the quality and quantity of vegetables grown by natives in the reserves' (Annual Report, Marandellas 1925). However, in Zimbabwe, dambo cultivation was prohibited during the colonial times due to environmental hazards associated with their utilization, i.e. soil erosion (Rattray et al. 1953). In addition, the land capability classification system of Zimbabwe places dambos in Class V, which denotes that the soils are not suitable for cultivation (Ivy 1981). The utilization of dambos was governed by the Natural Resources Board (NRB) which has been replaced by the Environmental Management Act of 2007. The realization of the farming potential of these seasonal wetlands has been restricted through various prohibitive measures enshrined in the legislation. Nonetheless, these legislations were largely ignored country-wide (White and Robinson 2008). After independence in 1980, the cultivation of dambos increased largely due to frequent crop failures in upland fields and relaxed policing of legislation. Climate change and variability has resulted in increased frequency of crop failure in upland fields and, consequently, increased food insecurity among the smallholder 
community in Zimbabwe and in response smallholder farmers have resorted to the cultivation of dambos which are seasonally saturated and are more fertile. Similar observations were also made by Kuntashula et al. (2006) in a study in Chipata, Zambia, where he reported that frequent droughts that have characterized southern Africa and poor performance of rain-fed crops in upland fields have resulted in mounting pressure on dambos that has been evident in the last few years.

In many arid and semi-arid regions, the capacity of wetlands to retain moisture for long periods and sometimes throughout the year and high fertility associated with these wetlands have resulted in their widespread use for cultivation (Russell 1971, McCartney et al. 2005). Several studies (Perera 1982, Bell et al. 1987, Kundhlande et al. 1995) have established that dambos are strategic resources worth exploiting for food production to cope with hunger that is manifested particularly during drought years. Dambos are a potentially valuable resource for agricultural purposes due to their widespread occurrence, saturation and inundation for months during rainy seasons, and high fertility when compared with uplands. In Malawi, it was suggested that low upland productivity, arising from both biological and physical factors, other than land pressure, partly influenced the exploitation of dambos (Mloza-Banda 2005). In many developing countries, particularly in Africa, wetlands, such as dambos, have been perceived by some as the 'new frontier' for agriculture (Woods 2009). Hence, it is projected that with the changing climate patterns, the number of farmers cultivating dambos will further increase. Dambos provide a good regular supply of crops, among them being vegetables, rice, tsenza (Cleus esculentus) and maize for home consumption and for sale in urban centres. For poor rural households that are short of food, wetlands can provide a life-saving safety net and wetlands represent a development opportunity which can lead them out of poverty (McCartney et al. 2010). Whitlow (1985) suggested that there is a need to re-assess the role of dambos in peasant farming, while Kuntashula et al. (2006) suggested that 'a good example of agricultural intensification that requires serious consideration is vegetable production in seasonal wetlands (dambos) in southern Africa'.

Although dambo cultivation brings significant benefits in terms of food security, health and income, poor cultivation practices can result in deleterious environmental impacts (e.g. reduced soil fertility, hydrology and biodiversity), which have harmful consequences to livelihoods (McCartney et al. 2010). Therefore, to avoid degradation of this fragile ecosystem, while sustaining optimum benefits, there is need to promote sustainable dambo cultivation practices and to use soil quality indicators such as soil organic carbon (SOC) to monitor changes in cultivated dambos. Sustainable cultivation of dambos will also reduce extensive soil erosion, which is a major hazard associated with their earlier restricted use. This erosion hazard still exists in dambos although we do not have update figures on its extent. The increased reliance on dambo cultivation in smallholder areas of Zimbabwe necessitates the need to explore current extent of dambo utilization, benefits and hazards associated with dambo cultivation, and sustainable wetland utilization options. Therefore, the objectives of this review were to evaluate the extent of dambo cultivation, evaluate the impact of dambo utilization on household food security, discuss the hazards that are associated with dambo utilization and explore options for sustainable dambo utilization in the smallholder farming areas. We hypothesized that dambo cultivation is widespread in the smallholder farming sector and is used as a climate change and variability adaptation strategy that has resulted in improved household food security.

\section{Materials and methods}

\subsection{Study site}

Zimbabwe is located in southern Africa between $19^{\circ}$ and $30^{\circ}$ south of the equator. The country has a total land area of 39 million ha. Food security in most smallholder farming areas of southern 
Africa mainly depends on rain-fed staple crop production, including cereals. More than one and a half million farming households in the smallholder settlements are located on about $49 \%$ of the country's agricultural land, of which $>70 \%$ is in marginal natural regions (NRs) IV and V. Most of the smallholders farming areas are in the marginal agro-ecological regions which have (i) low rainfall, (ii) severe dry spells and (iii) shallow sandy soils of low fertility (FAO 2006). The annual rainfall in Zimbabwe ranges from 500 to $1500 \mathrm{~mm}$, with a rainy season from November to March. The average annual temperature is $25^{\circ} \mathrm{C}$. The data on current dambo farming practices were collected from literature (published and unpublished materials), and surveys and field observations were conducted between 2010 and 2012.

\section{Results and discussions}

\subsection{Extent of dambo utilization as gardens by households in Zimbabwe}

In the smallholder farming areas, dambos have three major functions which are garden cultivation, pastures for grazing and domestic water supply (Dambo Research Unit 1987). Garden cultivation is important as it ensures household food security. Dambos are cultivated because of their high fertility and ready supply of water (McCartney et al. 2005, Kuntashula et al. 2006). In most smallholder areas, dambos are considered as a communal resource for which every member of the community has potential access to. In Zimbabwe, the area occupied by dambos is 1.28 million ha (Whitlow 1984, 1985, Dambo Research Unit 1987) compared with only 11,000 ha of formal small-scale irrigation schemes (FAO 1997a); hence, dambos should be recognized as an important resource for cultivation.

A study by Bell et al. (1987) reported variation in dambo utilization by regions. Those with access to dambos were $56 \%, 92 \%, 96 \%$ and $64 \%$ for Gutu, Zvimba, Chizengeni (Chiota) and Bumburwi (Chiota), respectively. However, utilization levels were 38\%, 80\%, 88\% and 46\% for Gutu, Zvimba, Chizengeni (Chiota) and Bumburwi (Chiota), respectively, by those who had access to dambo gardens. Nyamadzawo et al. (2013) reported that $100 \%$ of respondents who had access to wet dambos utilized them in Kashumbamhere and Chizengeni (Chiota). The demand for dambos has been increasing and more farmers are cultivating dambos. Those who initially did not have access to dambo gardens were given dambo gardens to cultivate by the headmen and the councillor in consultation with the extension officers. However, of late, there has not been any allocation because all the land which is suitable for dambo cultivation has been taken up. Nyamadzawo et al. (2013) reported that a third of the households in Kashumbamhere and Chizengeni villages in Chiota smallholder farming area have been cultivating dambos for five years or less showing a recent surge in dambo cultivation.

In the smallholder farming areas of Zimbabwe, the size of dambo gardens per household ranges from 0.06 to 5 ha (Bell and Roberts 1991, Nyamadzawo et al. 2013). In a recent study in Chiota smallholder farming area, Nyamadzawo et al. (2013) reported that only 1\% had $<1$ ha that could be used for dambo gardens, $74 \%$ of the respondents had at least $1 \mathrm{ha}, 18 \%$ had at least 2 ha, while 7\% had 3-5 ha available for use as gardens. Bell and Roberts (1991) and O'Sullivan (1988) reported that the average size of dambo gardens were 0.06, 0.18 and 0.50 ha for Gutu, Zvimba and Chiota smallholder farming areas, respectively. The sizes of dambo gardens varied with NRs. Dambos in drier areas such as Gutu (NR IV) usually dry out during the driest part of the year (August-October), and hence households have smaller dambo gardens to reduce strain on the water resources. In wetter areas such as Chiota and Zvimba (NR II), the size of dambos is larger, resulting in bigger gardens per household. In addition, Chiota and Zvimba are also located within marketing distance of Harare (60$100 \mathrm{~km})$, while Gutu is further away $( \pm 200 \mathrm{~km})$ from any major urban market (Bell and Roberts 1991). In Chiota, the average sizes of dambo gardens have increased to 1 ha 
(Nyamadzawo et al. 2013) from reported averages of 0.18 and 0.5 ha (Bell and Roberts 1991). However, a few farmers (7\%) had larger dambo gardens, averaging $3-5$ ha as they were allocated the gardens earlier before demand was high (Nyamadzawo et al. 2013).

\subsection{Crops grown in dambos}

In dambo gardens, both horticultural crops and cereals such as maize (Zea mays) and rice (Oryza sativa) are grown. Similar observations were made earlier in the century (Brown 1899; Selous 1920; Jollie 1924; the Native Commissioner Annual Report, Marandellas 1925) indicating that local knowledge on dambo cultivation has been passed on from one generation to another. In dambos, over 30 different types of crops were grown in the smallholder farming areas of Zimbabwe and crop production in dambos occupied the entire calendar year (Dambo Research Unit 1987). In some of the smallholder farming areas, such as Chiota, all farmers grew maize in the dambo gardens for household food security as they were no longer growing maize in upland fields because of perennial crop failures. Maize and rice are grown in dambo gardens from early spring (August-September) using residual moisture. Maize is harvested as green mealies (Shimada 1994) and for grain. Early maize from dambos helps to alleviate the 'hunger period' usually between September and January (Orr and Ritchie 2004).

Vegetables are also grown in dambos (i) for household consumption and (ii) for sale to local and urban markets. Carrots (Daucus carota) and rape (Brassica napus) are the most common horticultural crops grown and were given the biggest hectarage (Nyamadzawo et al. 2013). However, kale (Brassica oleracea) is a significant source of vegetable as it is perennial unlike rape which is seasonal and mainly grown between March and October. Other crops such as Irish potatoes (Solanum tuberosum), sweet potatoes (Ipomoea batatas), cucumber (Cucumis sativa (LINN.)), peas (Pisum sativum), tsenza (C. esculentus) and beans (Phaseolus vulgaris) are also grown in dambo gardens. However, the size of area under the different vegetables is determined by available resources and inputs (size of land, seed and fertilizers), the demand and market price of the product (Shimada 1994).

\subsection{Benefits of cultivating dambos over upland fields}

Dambos are cropped because they have better soil fertility and soil moisture resulting in their ability to support several crops in a year (Bell and Roberts 1991). The utilization of dambos all year round adds diversity and increases the possibility of supporting different livelihoods and combinations of livelihoods (Kuntashula et al. 2006). A summary in Table 1 shows that dambo soils have higher clay contents (15-30\%), SOC and $\mathrm{N}$ than their respective upland soils (Bell and Roberts 1991, Grant 1995, Nyamadzawo et al. 2013). Higher clay and SOC contents translate to higher cation exchange capacity (CEC) and better fertility relative to upland fields. Higher SOC is critical to soil productivity and generally corresponds to nutrient buildup. Nitrogen mineralization from soil organic matter (OM) may contribute most of the available $\mathrm{N}$ in sandy dambos. SOC increases the CEC of the surface soil which is especially important in light-textured soils such as sandy dambos in Chiota with low CEC. Agboola (1994) reported that $80 \%$ of CEC and available $\mathrm{P}, \mathrm{K}, \mathrm{Mg}$ and Ca were highly correlated with SOC levels in some West African Alfisols.

Cultivating dambos has resulted in significant improvement of household food security as households who cultivated dambos harvested enough maize for their household needs (Dambo Research Unit 1987, Orr and Ritchie 2004, Nyamadzawo et al. 2013). Dambo gardens also provided additional foods such as sweet potatoes and Irish potatoes for household consumption which ensured household food security. The Dambo Research Unit (1987) reported that during 
Table 1. A comparison of soil properties in uplands fields and dambo gardens.

\begin{tabular}{lcccc}
\hline & $\begin{array}{c}\text { Upland (Bell and } \\
\text { Roberts 1991) }\end{array}$ & $\begin{array}{c}\text { Dambo (sand vlei) (Bell } \\
\text { and Roberts 1991) }\end{array}$ & $\begin{array}{c}\text { Sand vlei } \\
\text { (Grant 1995) }\end{array}$ & $\begin{array}{c}\text { Dambo (sand vlei) } \\
\text { (Nyamadzawo et al. 2013) }\end{array}$ \\
\hline \% Clay & 6 & $20-30$ & $12.1^{\mathrm{a}}(11.1)$ & 15 \\
Soil N \% & $0.04-0.05$ & & 0.5 & 0.09 \\
SOC (\%) & $0.9-1$ & $2^{\mathrm{a}}$ & $1.5^{\mathrm{a}}(2.1)$ & $1.95^{\mathrm{a}}(3.3)$ \\
$\mathrm{P}\left(\mathrm{mg} \mathrm{kg}^{-1}\right)$ & 6.0 & 11.0 & 5 & 3.9 \\
$\mathrm{CEC}$ & $1.9 \%$ & $6.2(5-10) \%$ & & $5.6\left(\mathrm{CaCl}_{2}\right)$ \\
$\mathrm{pH}$ & 5.5 & 6.0 & & $330-399$ \\
$\mathrm{~N}\left(\mathrm{~kg} \mathrm{ha}^{-1}\right)$ & 120 & & & - \\
$\mathrm{P}\left(\mathrm{kg} \mathrm{ha}^{-1}\right)$ & 21 & & & 5.2 \\
\hline
\end{tabular}

${ }^{a}$ Average SOC for the whole dambo (margin, mid-slope, lower slope and bottom) and the number in bracket () is the SOC value of the cultivated mid-slope section.

the drought year of $1969 / 1970,84 \%$ of the households who cultivated dambos had enough food, while only $21 \%$ of those who cultivate uplands had enough food. In Zambia, Kuntashula et al. (2006) reported that frequent droughts that have characterized southern Africa and the associated dismal performance of rain-fed crops have resulted in mounting pressure on the use of dambos. In addition, to improved food security, smallholder farmers who cultivated dambos get additional income to purchase other household food requirements such as sugar and flour which they did not produce in the dambo gardens. In the smallholder farming areas, dambo gardens provided the single largest source of income for meeting household needs such as paying for school fees, buying fertilizers, agrochemicals, herbicides, livestock, fencing materials, scotch carts, bicycles, water engines, garden hoses and building better houses (brick under roofing sheets) (Dambo Research Unit 1987, Shimada 1994, Nyamadzawo et al. 2013). An example of two farmers who were utilizing 1 ha of upland and dambo, respectively, is given in Table 2 . The data in Table 2 were collected from Chiota between 2010 and 2012 and it shows that dambo enterprises generate more income per ha than cropping in the uplands.

Due to improved household food security in the area, Chiota has not been on government or non-governmental organizations food assistance programmes even during drought years. Chiota which is in Marondera district was ranked 48/57 in terms of food aid needs ( 1 being urgent need and 57 least need) and the possible explanation was that majority of the households were closer to the major urban areas and they relied on fruits and vegetables that were sold to urban areas (SADC 2002). In addition, cultivation of dambos has resulted in improved housing for the population, e.g. $77 \%$ of the households in Chiota an area of intense cultivation had brick houses that were either under asbestos, iron roofing sheets or tiles, compared with $23 \%$ that had grass-thatched houses (Nyamadzawo et al. 2013). Similar observations were also reported by Shimada (1994) in Northern Zambia and can also be seen in other areas of Zimbabwe such as Domboshawa, Murehwa and Mutoko where dambo cultivation is heavily practised.

\subsection{Land preparation and soil fertility management practices in dambo gardens}

Land preparation in dambo gardens is an all year round activity as land is prepared soon after removing one crop in preparation for the next crop. However, land preparation was mostly avoided during the wettest part of the season (December-February) because of difficulties in traction in dambos as they would be waterlogged. In dambo gardens, the most common cultivation method was the ox drawn plough (Nyamadzawo et al. 2013). This was preferred because it is faster and ox draught power was locally available for the majority of the farmers. Those who did not own oxen had their fields ploughed by those with oxen for a fee. However, other land 
Table 2. Estimated incomes generated from a farmer utilizing 1 ha of upland fields compared with 1 ha dambo in Chiota samllholder farming area.

\begin{tabular}{|c|c|c|c|c|c|c|c|c|c|c|c|}
\hline \multicolumn{6}{|c|}{ Upland } & \multicolumn{6}{|c|}{ Dambo } \\
\hline Crop & Yield & $\begin{array}{l}\text { Inputs } \\
\text { (US\$) }\end{array}$ & $\begin{array}{l}\text { Selling } \\
\text { price } \\
\text { (US\$) }\end{array}$ & $\begin{array}{l}\text { Gross } \\
\text { income } \\
\text { (US\$) }\end{array}$ & $\begin{array}{l}\text { Net } \\
\text { income } \\
\text { (US\$) }\end{array}$ & Crop & Yield & $\begin{array}{l}\text { Inputs } \\
\text { (US\$) }\end{array}$ & $\begin{array}{l}\text { Selling } \\
\text { price } \\
\text { (US\$) }\end{array}$ & $\begin{array}{l}\text { Gross } \\
\text { income } \\
\text { (US\$) }\end{array}$ & $\begin{array}{c}\text { Net } \\
\text { income } \\
\text { (US\$) }\end{array}$ \\
\hline Maize & $\begin{array}{l}1 \mathrm{t} / \mathrm{ha} \\
\text { on } \\
1 \text { ha }\end{array}$ & 160 & $260 / \mathrm{t}$ & 260 & 100 & $\begin{array}{c}\text { Maize on } \\
0.5 \text { ha }\end{array}$ & $1.5 \mathrm{t}$ & 80 & $\$ 260 / \mathrm{t}$ & 390 & 310 \\
\hline \multirow[t]{3}{*}{$\begin{array}{l}\text { Ground } \\
\text { nuts }^{\mathrm{a}}\end{array}$} & $0.1 \mathrm{t}$ & 20 & $800 / \mathrm{t}$ & 80 & 60 & $\begin{array}{r}\text { Rape on } \\
0.1 \text { ha }\end{array}$ & $\begin{array}{l}20 \text { bundles } \\
\quad \text { (biweekly) for } 7 \\
\text { harvests }\end{array}$ & 200 & \$4/bundle & 560 & 360 \\
\hline & & & & & & $\begin{array}{c}\text { Kale on } \\
0.2 \text { ha }\end{array}$ & $\begin{array}{l}30 \text { bundles } \\
\text { biweekly for } 12 \\
\text { months }\end{array}$ & 500 & \$4/bundle & 1440 & 940 \\
\hline & & & & & & $\begin{array}{c}\text { Carrots on } \\
0.2 \text { ha }\end{array}$ & $40 \times 50 \mathrm{~kg}$ bags & 600 & $\$ 35 /$ bag & 1400 & 800 \\
\hline $\begin{array}{l}\text { Total } \\
\text { (US\$) }\end{array}$ & & 180 & & 340 & 160 & & & 1280 & & 3490 & 2410 \\
\hline
\end{tabular}

Notes: Data on yields collected during a survey in 2010. Data on yields were collected between 2010 and 2012. Vegetable bundle $=100$ leaf bundle and ha $=$ hectare. ${ }^{\mathrm{a}}$ Groundnut is intercropped with maize on 1 ha. 
preparation methods such as zero tillage and digging using hoes were also practised by some households. Before ploughing, some famers used sickles to clear the land, some burnt the grass, some cleared the land using hoe, while others used zero tillage, herbicides and grazing animals in the land before ploughing. Practices such as burning of the grass before ploughing were carried out because of their convenience.

Although dambos are fertile relative to the uplands, continuous cultivation has resulted in decreasing soil fertility in cultivated dambos when compared with virgin dambos (Grant 1995). In response to declining fertility, farmers used a wide range of soil fertility amendments and at times more than one amendment was used in combination. Cattle manure was the most common form of amendment that was applied in most dambo gardens. In most of the smallholder farming areas, cattle manure use is very high, and in Chiota, the application rates ranged from 8.9 to $11.8 \mathrm{tha}^{-1}$ (Nyamadzawo et al. 2013). Nyamadzawo et al. (2013) reported that, though only $54 \%$ of the respondents owned cattle, $91 \%$ of the household used cattle manure in their gardens because those who did not own livestock had access to the manure which they would collect from the common grazing lands/pastures. High rates of manures were applied because most of the manure from the smallholder areas is of low nutrient content $(\sim 0.7 \% \mathrm{~N})$ and most farmers realized that at low application rates, the response of crops to the application of organic manure was poor. Mugwira and Mukurumbira (1984) suggested that the low nutrient contents in cattle manures has resulted in limited effectiveness in improving plant growth and crop yields. Grant (1967) also submitted that manures from smallholder farming areas were generally of low quality with a lot of sand and maize stover. It was suggested that the benefits from fertilizing with manure stem more from the bases released than from the supply of $\mathrm{N}$ and $\mathrm{P}$. In response, most farmers applied a mixture of inorganic fertilizers and cattle manure in dambo gardens to supply the deficient nutrients.

To supplement cattle manure, other sources of amendments were also applied in the dambo gardens and these included termitaria (termite mount soil) and leaf litter (murakwani) mainly because they were freely available and the farmers said these amendments improved soil structural stability, water holding capacity and plant growth. In addition, farmers applied locally available amendments, e.g. compost which is made from garden, household and poultry wastes which were all found within the community. Most of the additional amendments were applied by the resource-constrained farmers who could not afford applying large quantities of manures from livestock, either because they did not have livestock and could not gather and collect enough cattle manure from the pastures or because they had a small herd of cattle which did not produce enough manure to meet their needs.

Besides using organic manures, farmers also applied very high rates of inorganic fertilizers to sustain the intense crop production in dambo gardens, when compared with uplands. In dambo gardens, farmers used compound D (7:14:7 for NPK) or compound X (1:1 mixture of $34 \%$ Ammonium Nitrate and compound D) at application rates of $1 \mathrm{tha}^{-1}(\sim 70-205 \mathrm{~kg} \mathrm{~N}$, $140 \mathrm{~kg} \mathrm{P}$ and $70 \mathrm{~kg} \mathrm{~K}$ ), (Nyamadzawo et al. 2013). However, some farmers used manure $(0.7 \% \mathrm{~N})$ at rates as high as $57 \mathrm{tha}^{-1}(\sim 399 \mathrm{~kg} \mathrm{~N})$ instead of inorganic fertilizers. Similarly, high inorganic fertilizer application rates of $\sim 800 \mathrm{~kg} \mathrm{ha}^{-1} \mathrm{AN}\left(\sim 272 \mathrm{~kg} \mathrm{ha}^{-1} \mathrm{~N}\right)$ in smallholder gardens were also reported by Mapanda et al. (2011) compared with upland fields where farmers applied only $21 \mathrm{~kg} \mathrm{P}$ and $120 \mathrm{~kg} \mathrm{~N}$ (Mugwira and Mukurumbira 1984, Nyamangara and Nyagumbo 2010). These high fertilizer application rates especially inorganic $\mathrm{N}$ and $\mathrm{P}$ can potentially cause environmental problems such as surface and ground water pollution. High $\mathrm{N}$ application can result in increased $\mathrm{N}_{2} \mathrm{O}$ emission and practices such as application of cattle manure and other amendments can potentially mitigate greenhouse gas (GHG) emissions. However, no study has so far quantified the mitigation benefits of the farmer practices and this calls for further research. 


\subsection{Effects of dambo cultivation on hydrology and water management practices in dambo gardens}

Water conservation is a critical aspect of dambo cultivation. Dambos are the sources of most streams and rivers in Zimbabwe. There are fears that the use of dambos may result in drying up of dambos and rivers; however, earlier studies by Dambo Research Unit (Dambo Research Unit 1987) showed that the impact of dambo cultivation on stream flow is minimal. von der Heyden and New (2003) reported that $98 \%$ of dambo catchment input was lost to evapotranspiration, showing that little water from dambos contributes to stream flow. These studies reported that dambos contributed significantly to wet season flow, but they did not contribute significantly to dry season flow of most rivers. However, differences between numerous publications have been reported with regard to effects of dambos on catchment stream flow and base flow (e.g. Balek and Perry 1972, Bell et al. 1987, Stewart 1989, McCartney et al. 1998). The evidence given by these different reports are contradictory and there is no consensus on the influence of dambos on downstream flow regime.

With the recent surge in dambo utilization, the continual exploitation of dambo water may result in reduced water availability. A study by Nyamadzawo et al. (2013) reported that some farmers acknowledge that dambos are drying up and some farmers were failing to put crops during the driest parts of the year (August-October). Most of the farmers acknowledged that drying up of wells started only a few years back, as most wells did not dry up when they started cropping dambos. Mabeza and Mawere (2012) also reported reduced production in gardens in $81.7 \%$ of the households in Seke smallholder farming area during the months of October and November because water was running out. The drying up of wells in dambo gardens could be a result of over exploitation of the water resources as growing of cash crops in dambos is lucrative business and as a response to climate change and variability, resulting in dambos being preferred to uplands for crop production. The drying of dambos can result in increased oxidation of stored $\mathrm{SOC}$, thus reversing the $\mathrm{C}$ sequestration benefits of dambos. However, to date there is no consensus on the impacts of dambo cultivation on the hydrology of streams and rivers, especially in view of the recent increase in intensity of cultivation, and this calls for further research.

To adapt to this challenge of drying dambos, farmers are using a variety of strategies to reduce water usage and infield water losses. The strategies used in conserving water include using water engines and irrigation pipes than traditional methods such as canal irrigation and flood irrigation to reduce transmission losses. However, the watering remained the most commonly used method of transmitting water. In addition, farmers use other infield water conservation strategies and similar practices were reported in cultivated dambos in Malawi by Chadanti-Malunga (2011). Some of the water conservation strategies that are used included irrigation at sunset, mulching, organic manuring, ridging, deep planting and potholing in the vegetable beds. These strategies ensure maximum utilization of irrigation water and reduced losses due to evaporation and runoff and are aimed at conserving the dwindling water resources especially during the driest part of the year (August-October). In addition, farmers are also using some drought tolerant and early maturing varieties to cope with reduced water availability in dambo gardens.

\subsection{Dambo cultivation, lessons from the regions}

Dambo cultivation is not peculiar to Zimbabwe alone but is also widely practised in other countries such as Zambia, Malawi, Uganda, Angola, Kenya, Mozambique, Rwanda, Uganda, the United Republic of Tanzania in East and Southern Africa (FAO 1997b). Several researchers have reported dambo utilization by smallholder farmers in the region, e.g. Chadanti-Malunga (2011) and Mloza-Banda (2005) in Malawi, and Perera (1982), Shimada (1994) and Kuntashula et al. (2006) in Zambia. In Malawi, dambos are estimated at 259,000 ha (12\% of land available for 
cultivation). However, Mloza-Banda (2005) suggested that their significance for the livelihoods of the populations having access to them is disproportionately greater than that suggested by their area. In Zambia, dambos occupy an estimated $12.5 \%$ of the land area ( $~ 7.5$ million ha) (SADC 2001) and have been reported to result in improved food security (Shimada 1994).

In most countries in the region, dambo utilization has resulted in improved livelihoods of the smallholder farmers. Mloza-Banda (2005) and Kuntashula et al. (2006) also suggested that low upland productivity, dismal performance of rain-fed crops and frequent droughts that have characterized southern Africa have increased the pressure and exploitation of dambos. Periodic droughts in Zambia and Malawi and most of southern Africa have rapidly increased, causing alarming seasonal food and fresh water shortages especially during the dry seasons. As a result, many people in Malawi, Zambia and Zimbabwe use dambos for agriculture and these dambos provide enough food for local consumption and surplus for the market. However, efforts to develop dambos agriculturally have been hampered by a limited research on sustainable agricultural practices and the hydrology and soils of dambos, which have proved to be variable and complex (FAO 1998a).

The cultivation of dambos is not peculiar to central and southern Africa alone. Other patched or seasonal wetlands are also extensively cultivated in sub-Sahara Africa. The patch systems of dambos show closer resemblance to inland valleys of West Africa commonly known as fadamas in Nigeria and bolis (Sierra Leone). Inland valleys are defined as the upper reaches of river systems, inland in respect of the main rivers and tributaries, in which river alluvial sedimentation processes are absent or of minor importance: they have only a minor floodplain and levee system (Windmeijer and Andriesse 1993). Just like dambos, inland valleys comprise the toposequence, or continuum, of valley bottoms and minor floodplains which may be submerged for part of the year, their hydromorphic fringes and contiguous upland slopes and crests, extending over an area that contributes runoff and seepage to the valley bottom. Furthermore, patched dambo systems also resemble inland basins which do not drain to an ocean. Inland basins are extensive drainage depressions consisting of alluvial deposits that border rivers and inland valleys, or flat floored or relatively shallow valleys such as fadamas or dambos. Inland basins are also cultivated because of their higher soil fertility. In West Africa, some $10-25 \%$ of inland valleys are being cultivated, mainly by smallholders who grow rice at yields of around $1 \mathrm{tha}^{-1}$ (FAO 1998b). However, like dambos, much of the research effort in inland valleys and inland basins has been geared towards alleviating productivity constraints than on sustainable development of inland valleys. In West Africa, little attention has been paid to establishing the ecological value of inland valley agro-ecosystems, compartments thereof or processes therein (FAO 1998b). Therefore, there is need to balance productivity-driven decision-making and the conservation and sustainability objectives.

\subsection{Erosion hazards associated with dambo utilization}

Dambo cultivation has provided a development opportunity and a poverty reduction strategy for many poor smallholder farmers. However, care is needed to ensure that this 'new frontier' for agriculture does not destroy other ecosystem services (e.g. carbon sequestration, soil erosion), and other means of food security (e.g. fisheries), also vital for poor people (McCartney et al. 2010). Erosion is one of the main hazards which previously led to the prohibition of dambo cultivation in Zimbabwe although cultivation is still widespread. Previous experiences have shown that the use of machinery on a large scale can cause erosion; however, the cultivation of dambo gardens on a small scale did not cause any significant erosion (Dambo Research Unit 1987, Whitlow, 1992, 1994, McNeely 2008). Unfortunately, we do not have current data on erosion or other associated environmental risks from dambos especially with the recent increase in dambo cultivation (Kotze 2013) and this call for further research. Dambo cultivation also 
results in a reduction in SOC (Kundhlande et al. 1995). Reduced SOC is also linked to increased soil erosion as aggregate stability is reduced and the soil is easily washed away. Cultivation also exposes the large SOC stocks that are stored in dambos to microbial breakdown and this can result in increased $\mathrm{CO}_{2}$ emissions to the atmosphere, causing global warming. The cultivation of dambos, therefore, reverses the $\mathrm{C}$ sequestration role of these seasonal wetlands. In addition, when a dambo is cultivated, surface cover is removed and the soil is exposed to direct raindrop impact especially during early plant growth stages. Therefore, there is need for further research on the role of cultural practices on, e.g. crop rotations and the integration of cover crops on soil erosion in dambos. There is also need to evaluate potential benefits of mulch retention in dambo gardens compared with the current practices were there is net biomass transfer from the gardens. In addition, the use of climate smart agriculture (CSA) practices such as agroforestry, mulch and conservation agriculture (CA) on soil erosion in cultivated dambos should also be evaluated. Besides reducing soil erosion, these practices also reduces water losses due to evaporation and runoff. However, presently the magnitude of the benefits of both cultural practices and CSA on soil erosion has not been quantified.

\subsection{Future directions for sustainable dambo utilization in the smallholder farming areas of Zimbabwe}

Dambo cultivation is one climate change and variability adaptation strategy that has provided an opportunity for self-reliance and improved household food security in the smallholder farming areas. However, cultivation of dambos results in a reduction in the soil chemical, physical and biological qualities. Management practices by most farmers in dambo gardens are complex and are sometimes governed by limited availability of resources. Hence, there is need for improved management of dambos to increase the net benefits derived from them and reduce the detrimental effects. It is becoming increasingly clear that to face the food challenge over the coming 50 years, combined efforts of developing sustainable CSA will be required (Rockström 2002). However, irrigation is too costly to make an impact on rural households' food security in the near future, and climate smart dambo cultivation can be a sustainable option.

CSA options can enable farmers to maintain soil fertility, reduce soil degradation and conserve water and allow for the sustainable production in this 'new frontier for agriculture'. What is needed is a balance: appropriate farming practices that support sustainable food production and protect ecosystems (Burness Communications 2011). CSA practices build climate resilience across a range of possible climate futures and build greater resilience of the agricultural sector to the shocks of climate change while also ensuring the attainment of improved livelihoods and food security besides mitigating climate change. Examples of CSA practices include various forms of agroforestry, improved manure management and intercrops.

Agroforestry has great potential to improve household food security, climate change adaptation and mitigation. The food security benefits of agroforestry include increases in yields of staple cereal crop, provision of fruits, nuts and other edible products. For example, legume trees used in agroforestry have substantially increased maize yields in Zimbabwe, Zambia and Malawi (Kwesiga et al. 1999, Mafongoya and Dzowela 1999, Ajayi et al. 2005, Nyamadzawo et al. 2012). The climate change adaptation benefits of these trees in the maize cropping system include increase in soil OM, enhance biological diversity, reduced erosion and improved microclimate that allows associated crops to be productive even under extreme climate events. Agroforestry plays a very important role in $\mathrm{C}$ sequestration when compared with conventional systems. Studies in Zimbabwe showed that fallow species sequestered between 9.0 and 5.6 $\mathrm{Mg} \mathrm{Cha}^{-1}$, in the $0-20 \mathrm{~cm}$ depth in just two seasons (Nyamadzawo et al. 2012). Mitigation of GHG is through increased photosynthesis which reduces atmospheric concentrations of $\mathrm{CO}_{2}$ 
and through increased storage of carbon in the soil. Nitrous oxide and $\mathrm{CO}_{2}$ emissions from soils are reduced and the $\mathrm{CH}_{4}$ sink strength increased under agroforestry compared with conventional cropping systems. In Malawi, Sesbania sesban has been reported to do well in dambos (Waddington et al. 1997, Phiri et al. 1999). However, the benefits of such CSA practices have not been explored in dambo gardens in Zimbabwe, hence the need for further research.

The use of organic sources of manures in dambo gardens may be better placed as a way of maintaining soil fertility and also as a mitigation option against soil emissions of GHGs than the use of mineral $\mathrm{N}$ fertilizers which increases soil fertility but results in high soil emissions. Studies by Dick et al. (2008) showed a $158 \%$ increase in $\mathrm{N}_{2} \mathrm{O}$ emissions following the application of urea compared with $63 \%$ after applying organic manures in Mali. Similar observations were also made by Mapanda et al. (2011) in Zimbabwe. Organic manure releases nutrients slowly, reducing the risk of leaching and improves soil water retention and microbial activities (Munthali 2007). During dambo cultivation, high inorganic $\mathrm{N}$ inputs are applied and some of the $\mathrm{N}$ is lost as $\mathrm{N}_{2} \mathrm{O}$. The $\mathrm{N}$ that is leached is a possible source of groundwater contamination whose extent is still to be determined. The current farmer management practices in dambo gardens have resulted in the build-up of high P concentration in the plough layer (Nyamadzawo et al. 2013). Although P is not mobile, it may be a problem when it is eroded and is deposited into surface waters. However, the extent of erosion and $\mathrm{P}$ losses from dambo gardens is currently unknown, thus there is need for future studies on this area. The use of organic manures demonstrates the basic principles that farmers adapted to their local conditions and household resource constraints can produce more and at the same time mitigating GHG emissions from using CSA cropping systems. Improving manure quality, and quantity that is collected, is a potential solution to low productivity levels and it reduces the smallholder farmers' vulnerability to drought, and increases household food security and resilience to climate change.

In most smallholder farming areas, organic wastes in the form of plant residues, garden wastes and other unwanted material are disposed off through burning which increases atmospheric concentrations of GHGs. Though burning is an important management practice, it affects the atmospheric concentrations of GHGs, e.g. nitrous oxide $\left(\mathrm{N}_{2} \mathrm{O}\right)$ and carbon dioxide $\left(\mathrm{CO}_{2}\right)$. The Intergovernmental Panel on Climate Change attributes $17.3 \%$ of total anthropogenic emissions to biomass burning, making it the second largest source of GHGs from human activities after the burning of fossil fuel. In tropical areas such as Zimbabwe, pyrogenic emissions are mostly concentrated in the dry season (July-October) (Scholes and Andreae 2000). Burning causes significant $\mathrm{N}$ and $\mathrm{C}$ losses from seasonally dry ecosystems. Harnessing of huge quantities of biomass that are burnt to produce biochar is a potential sustainable management option in the smallholder farming areas. The production of biochar from bio-wastes, and its subsequent application to agricultural soils such as dambo gardens, has the potential to minimize environmental risks while enhancing soil quality (Lehmann et al. 2008). Moreover, due to its long residence time, biochar application to soils mitigates GHG emissions via carbon sequestration (Lehmann et al. 2008, Free et al. 2010, Laird et al. 2010, Van Zwieten et al. 2010). Although biochar research in Zimbabwe is still limited, studies conducted elsewhere demonstrated the capacity of biochar to enhance soil structure, nutrient availability, moisture retention and crop productivity, hence it can potentially play an important role in maintaining soil fertility and the $\mathrm{C}$ sequestration role in dambos. Besides the production of biochar from plant residues, incorporation of plant residues has potential to increase soil carbon stocks, fertility and soil quality. However, no studies have been carried out to evaluate the impacts of residue incorporation in dambos.

The use of CA can be another sustainable option that can be adopted in dambo gardens by smallholder farmers. CA is generally defined as any tillage sequence that minimizes or reduces the loss of soil and water; and operationally is tillage or tillage and planting combination, which leaves at least $30 \%$ or more mulch or crop residue cover on the surface (SSSA 1986). 
In the dry lands of southern Africa, CA has been loosely applied to mean any tillage system that conserves or reduces soil, water and nutrient loss, or reduces draft power (human, animal and mechanical) input requirements for crop production (Twomlow et al. 2008). The use of CA in dambo gardens can therefore potentially increase $\mathrm{C}$ sequestration and crop productivity.

In addition, other CSA practices such as integrated nutrient management which involve (i) returning organic materials to the soil to replace SOC lost through decomposition, through practices such as green manuring, composting, etc., (ii) reducing evaporation losses through mulching, (iii) the integration of multipurpose trees into cropping systems, (iv) crop rotations of cereals and legume-based crops can be used. The use of water-saving irrigation techniques, e.g. drip irrigation, and renewable sources of energy like solar powered engines instead of diesel engines for irrigation will also need to be explored. However, there is need to mobilize resources and institutional support in order to carry out research on CSA models for use in smallholder farming areas and to upscale known, tried and tested CSA technologies.

\section{Conclusions and recommendations}

Dambo cultivation is a potentially beneficial farmer-driven climate change and variability adaptation strategy. Smallholder farmers are cultivating dambos which have higher soil fertility and are seasonally saturated, thus buffering themselves against drought-related crop failures and improved food security. The majority of the farmers no longer cultivate upland fields and they entirely depend upon growing crops in dambos. Dambo farming is indeed a 'new frontier for agriculture' in most semi-arid to arid smallholder farming areas. Though the cultivation of dambos has resulted in improved livelihood and food security in the smallholder farming areas, their improper use may result in their degradation through soil erosion, loss of SOC, soil fertility and reduced water availability. So far the little research that has been done on dambos has focused towards alleviating productivity constraints, while very little has been done to establishing the ecological value of dambos and to promote sustainable use of dambos. Thus, there is need for further research to evaluate the environmental sustainability of dambo utilization. There is need to optimize the benefits and reduce the detrimental effects of dambo cultivation. Sustainable intensification of agriculture is a priority for future food security, but we need to take a more holistic approach to balance production and conserving the environment. The use of sustainable CSA options such as agroforestry, biochar, CA and organic amendments are possible options that should be availed to the famers so that they can choose the best innovations to suit to their complex agronomic and socio-economic conditions.

\section{Acknowledgements}

We are grateful for the assistance given by Mr Ngoni Jiri, the AGRITEX officer for Chiota, and for the assistance by the Chiota community during data collection.

\section{Funding}

This work was supported by the International Foundation of Science (IFS) [grant C/4569-1]; DAAD Fellowship [grant number A/10/03022] and the Climate Food and Farming (CLIFF) network under the CGIAR Research Program on Climate Change, Agriculture and Food Security (CCAFS).

\section{References}

Acres, B.D., et al., 1985. African dambos: their distribution, characteristics and use. In: M.F. Thomas and A.S. Goudie, eds. Dambos: small channelless valleys in the tropics. Zeitschrift für Geomorphologie 52. Stuttgart: Borntraeger, 63-86. 
Agboola, A.A., 1994. A recipe for continuous arable crop production in the forest zone of Western Nigeria. In: P.A. Sanchez and H. Van Hauten, eds. Alternative to slash-and-burn agriculture, 15th International Soil Science Congress, Acapulco, Mexico. Nairobi: International Centre for Research in Agroforesry and International Society of Soil Sciences, 107-120.

Ajayi, O.C., et al., 2005. Impact of fertilizer tree fallows in Eastern Zambia. A study on impacts of agroforestry. World Agroforestry Centre 3rd EPMR. Nairobi: World Agroforestry Centre.

Balek, J. and Perry, J. E., 1972. Luano catchment reserve project. Lusaka: National Council for Scientific Research, Water Resources Research Report WR20.

Bell, M. and Roberts, N., 1991. The political ecology of dambo soil and water resources in Zimbabwe. Transactions of the institute of British geographers, 16 (3), 301-318.

Bell, M., et al., 1987. The use of dambos in rural development, with reference to Zimbabwe. Harare: Loughborough University/University of Zimbabwe Project, Final Report of ODA Project R3869.

Boast, R., 1990. Dambos: a review. Progress in physical geography, 14 (2), 153-177.

Branca, G., et al., 2011. Identifying opportunities for climate-smart agriculture investments in Africa. Rome: FAO.

Bratton, M., 1987. Drought, food and the social organisation of small farmers in Zimbabwe. In: M. Glantz, ed. Drought and hunger in Africa denying famine a future. New York: Cambridge University Press, 31-35.

Brown, W.H., 1899. On the South African frontier. London: Sampson, Low, Martson.

Bullock, A., 1992. Dambo hydrology in Southern Africa - review and reassessment. Journal of hydrology, $134(1-4), 373-396$.

Burness Communications, 2011. Radical overhaul of farming could be 'game-changer' for global food security. ScienceDaily [online]. Available from: http://www.sciencedaily.com/releases/2011/08/ 110822092309.htm [Accessed 23 October 2013].

Camberlin, P., et al., 2009. Components of rainy seasons' variability in Equatorial East Africa: onset, cessation, rainfall frequency and intensity. Theoretical and applied climatology, 98 (3-4), 237-249. doi:10.1007/s00704-009-0113-1.

Chadanti-Malunga, J., 2011. Adaptive strategies to climate change in Southern Malawi. Physics and chemistry of the earth, 36 (4), 1043-1046.

Cline, W., 2007. Global warming and agriculture: Impact estimates by country. Washington, DC: Center for Global Development and Peterson Institute for International Economics.

Dambo Research Unit, 1987. Utilisation of dambos in rural development. A discussion document prepared by the Dambo Research Unit Loughborough University, UK and University of Zimbabwe. Harare: University of Zimbabwe Publications.

Department of Meterological Services, 1981. Climate handbook of Zimbabwe. Harare: Department of Meterological Services.

Dick, J., et al., 2008. The contribution of agricultural practices to nitrous oxide emissions in semi-arid Mali. Soil use and management, 24, 292-301.

FAO, 1997a. Socio-economic impact of smallholder irrigation development in Zimbabwe [online]. Harare: FAO Document Repository, Regional Office for Southern Africa. Available from: http://www.fao.org/ docrep/x5594e/x5594e00.htm [Accessed 15 June 2013].

FAO, 1997b. Consultation on wetland characterization and classification for sustainable agricultural development in East and Southern Africa. In: Wetland characterization and classification for sustainable agricultural development [online], AGL/SAFR - 814. Harare: FAO. Available from: http://www.fao. org/DOCREP/003/X6611E/X6611E00.HTM [Accessed 16 August 2009].

FAO, 1998a. Wetland characterization and classification for sustainable agricultural development, PART III, Use of agro-ecological zones and resource management domains for sustainable management of African wetlands [online]. Harare: Food and Agriculture Organization of the United Nations (FAO) Sub-Regional Office for East and Southern Africa (SAFR). Available from: http://www.fao.org/ docrep/003/X6611E/x6611e03.htm [Accessed 16 August 2009].

FAO, 1998b. Wetland characterization and classification for sustainable agricultural development [online]. ISBN: 0797419284. Available from: http://www.fao.org/docrep/003/x6611e/x6611e00.HTM [Accessed 23 October 2013].

FAO, 2006. Fertilizer use by crop in Zimbabwe. First version, published by Food and Agriculture Organization of The United Nations. Rome: FAO.

Free, H.F., et al., 2010. The effect of biochars on maize (Zea mays) germination. New Zealand journal of agricultural research, 53, 1-4. 
Grant, P.M., 1967. The fertility of sandveld soil under continuous cultivation, Part II: the effects of manure and nitrogen fertilizer on the nitrogen status of the soil. Rhodesia Zambia Malawi journal agricultural research, $5,117-128$.

Grant, P.M., 1995. Fertility of dambo soils and the related response of dambo soils to fertilisers and manure. In: R. Owen, K. Verbeek, J. Jackson, and T. Steenhuls, eds. Dambo farming in Zimbabwe. Harare: University of Zimbabwe Publications, 117-126.

von der Heyden, C.J. and New, M., 2003. The role of dambos in the hydrology of a catchment and the river network downstream. Hydrology and earth system science, 7 (3), 399-357.

IPCC, 2007. Contribution of working group III to the fourth assessment report of the intergovernmental panel on climate change. In: B. Metz, et al., eds. Climate change 2007, fourth assessment report. Cambridge: Cambridge University Press, 121-167.

Ivy, P., 1981. A guide to soil coding and land capability classification for land use planners. Harare: Agritex. Jollie, E.T., 1924. The real Rhodesia. London: Hutchinson.

Kotze, D., 2013. Assessing the environmental sustainability of wetland cultivation. In: A. Wood., A. Dixon, and M. McCartney, eds. Wetlands management and sustainable livelihoods in Africa. Oxfordshire: Routledge, 304. ISBN 1136470638, 9781136470639.

Kundhlande, G., Govere, J., and Muchana, O.A., 1995. Socio-economic constraints to increased utilisation of dambos in selected communal areas. In: R. Owen, K. Verbeek, J. Jackson, and T. Steenhuls, eds. Dambo farming in Zimbabwe. Harare: University of Zimbabwe Publications, 87-96.

Kuntashula, E., et al., 2006. Farmer participatory evaluation of the potential for organic vegetable production in the wetlands of Zambia. Outlook on agriculture, 35 (4), 299-305.

Kwesiga, F.R., et al., 1999. Sesbania sesban improved fallows in eastern Zambia: their inception, development and farmer enthusiasm. Agroforestry systems, 47, 49-66.

Laird, D., et al., 2010. Biochar impact on nutrient leaching from a midwestern agricultural soil. Geoderma, $158,436-442$.

Lehmann, J., et al., 2008. Australian climate-carbon cycle feedback reduced by soil black carbon. Nature geoscience, $1,832-835$.

Mabeza, M.C. and Mawere, M., 2012. Dambo cultivation in Zimbabwe: challenges faced by small-scale dambo farming communities in Seke-Chitungwiza communal area. Journal of sustainable development in Africa, 14 (5), 39-53.

Mäckel, R., 1985. Dambos and related landforms in Africa: an example for the ecological approach to tropical geomorphology. In: M.F. Thomas and A.S. Goudie, eds. Dambos: small channelless valleys in the tropics. Zeitschrift für Geomorphologie 52. Stuttgart: Borntraeger, 1-23.

Mafongoya, P.L. and Dzowela, B.H., 1999. Biomass production of tree fallow and their residual effects on maize in Zimbabwe. Agroforestry systems, 47, 139-151.

Mapanda, F., et al., 2011. Effects of organic and mineral fertilizer nitrogen on greenhouse gas emissions and plant-captured carbon under maize cropping in Zimbabwe. Plant and soils, 343, 67-81.

McCartney, M.P., et al., 1998. Comparison of the hydrology of two contrasting headwater catchments in Zimbabwe. In: K. Kovar, U. Tappeiner, N.E. Peters, and R.E. Craig, eds. Hydrology, water resources and ecology in headwaters. IAHS Publication 248. Wallingford: International Association of Hydrological, Sciences, 515-522.

McCartney, M.P., Masiyandima, M., and Houghton-Carr, H.A., 2005. Working wetlands, classifying wetland potential for agriculture. Colombo: IWMI, Research Report 90.

McCartney, M., et al., 2010. Wetlands, agriculture and poverty reduction. Colombo: International Water Management Institute, 39, IWMI Research Report 137. doi:10.5337/2010.230, ISBN 978-92-9090734-3.

McNeely, J.A., 2008. Common ground, common future: how ecoagriculture can help feed the world and save wild biodiversity. Philadelphia: DIANE Publishing, 24.

Mloza-Banda, H.R., 2005. Integrating new trends in farming systems approaches in Malawi. African Crop Science Conference Proceedings, 7, 961-966. ISSN 1023-070X/2.

Mugwira, L.M. and Mukurumbira, L.M., 1984. Relative effectiveness of fertilizer and communal area manures as plant nutrient sources. Zimbabwe agriculture journal, 89 (6), 241-250.

Munthali, M., 2007. Integrated soil fertility management technologies: a counteract to existing milestone in obtaining achievable economical crop yields in cultivated lands of poor smallholder farmers in Malawi. Advances in integrated soil fertility management in sub-Saharan Africa: challenges and opportunities [online]. Available from: http://www.springerlink.com/content/t613142816267327/ fulltext.pdf [Accessed 25 June 2013].

Native Commissioner Marandellas, 1925. Annual Report NAZ S235/503. Salisbury: Government Printers. 
New, M., et al., 2006. Evidence of trends in daily climate extremes over southern and west Africa. Journal of geophysical research, 111, 2156-2202. doi:10.1029/2005JD006289.

Nyamadzawo, G., et al., 2012. Effects of pruning regimes on soil water and maize yields in coppicing fallowmaize intercropping systems in Central Zimbabwe. Agroforestry systems, 84, 273-286. doi:10.1007/ s10457-011-9453-9.

Nyamadzawo, G., et al., 2013. Effect of farmer management practices on the variability of soil organic carbon and vegetable yields from dambo gardens in Chiota smallholder farming area of Zimbabwe. Under Review. African Crop Science Journal.

Nyamangara, J. and Nyagumbo, I., 2010. Interactive effect of selected nutrient resources and tied ridging on plant growth performance in a semi-arid smallholder farming environment in central Zimbabwe. Nutrient cycling in agroecosystems, 88, 102-109.

Orr, A. and Ritchie, J.M., 2004. Learning from failure: smallholder farming systems and IPM in Malawi. Agricultural systems, 79, 31-54.

O'sullivan, M., 1988. The use of remote sensing methods to examine dambo cultivation in Communal Areas of Zimbabwe on an inter- and intra-regional scale. Unpublished B.Sc. dissertation. Department of Geography, University of Loughborough.

Palmer, R., 1977. Agricultural history of Rhodesia. In: R. Palmer, and Q.N. Parsons, eds. The roots of rural poverty in Central and Southern Africa. London: Heinemann, 221-254.

Perera, N.P., 1982. The ecology of wetlands (dambos) of Zambia, and their evaluation for agriculture - a model for the management of wetlands in sub-humid eastern and southern Africa. International journal of ecology and environmental studies, 8, 27-38.

Phiri, A.D.K., Kanyama-Phiri, G.Y., and Snapp, S., 1999. Maize and sesbania production in relay cropping at three landscape position in Malawi. Agroforestry systems, 47, 153-162.

Rattray, J.M., Cormack, R.M.M., and Staples, R.R., 1953. The vlei areas of S. Rhodesia and their uses. Rhodesian agricultural journal, 50, 465-483.

Rockström, J., 2002. Resilience building and water demand management for drought mitigation. In: Proceedings of the 3rd WaterNet/Warfsa symposium. Dar es Salaam, Tanzania: Water Demand Management for Sustainable Development, 1-11.

Russell, T.P.J., 1971. Dambo utilisation survey. Lilongwe: Lilongwe Land Development Programme.

SADC, 2001. Wetland development and management in Sothern Africa Development Community (SADC) countries. In: Proceedings of a sub-regional workshop, 19-23 November 2001. Harare.

SADC, 2002. Zimbabwe emergency food security assessment report [online], Zimbabwe National Vulnerability Assessment Committee in collaboration with the SADC FANR Vulnerability Assessment Committee. Available from: http://www.sadc.int/fanr/aims/rvaa/Documents/Zimbabwe/ July\%20-\%20August $\% 202002 \% 20 \% 20 Z$ Zimbabwe\%20Emergency\%20Assessment\%20Report.pdf [Accessed 16 February 2013].

Scholes, M. and Andreae, M.O., 2000. Biogenic and pyrogenic emissions from Africa and their impact on the global atmosphere. $A M B I O, 29,23-20$.

Scoones, I. and Cousins, B., 1991. Contested terrains: the struggle for control over Dambo in Zimbabwe. London: Drylands Programme, IIED.

Scoones, I., et al., 2010. Zimbabwe's land reform: myths and realities. London: James Currey, ISBN 978-184701-024-7; Harare: Weaver Press, ISBN 978-1-77922-110-0.

Selous, F.C., 1920. A hunter's wandering in Africa. London: Macmillan.

Shimada, S., 1994. Change in land use of Dambo at Chinena village of central Zambia. The science reports of the Tohoku University 7th Series, 44 (1), 3-22.

SSSA, 1986. Glossary of soil science terms. Madison, WI: Soil Science Society of America.

Stewart, J.B., 1989. Estimation of aerial evaporation from dambos in Zimbabwe using satellite data. Wallingford: British Geological Survey, The Basement Aquifer Research Report 1984-1989, 48-59.

Twomlow, S., et al., 2008. Lessons from the field - Zimbabwe's conservation agriculture task force. Journal of SAT agricultural research, $6,1-11$.

Van Zwieten, L., et al., 2010. Effects of biochar from slow pyrolysis of papermill waste on agronomic performance and soil fertility. Plant and soil, 327, 235-246.

Waddington, S.R., et al., 1997. Soil fertility research for maize-based farming systems in Malawi and Zimbabwe. In: Proceedings of the soil fertility network results and planning workshop, 7-11 July 1997. Zimbabwe: Africa University Mutare.

Windmeijer, P.N. and Andriesse, W., 1993. Inland valleys in West Africa: an agro-ecological characterization of rice-growing environments. Wageningen: International Institute for Land Reclamation and Improvement, 160, ILRI Publication 52. 
White, J.R. and Robinson, W.H., 2008. Natural resources: economics, management and policy. New York: Nova Science Publishers.

Whitlow, J.R., 1984. A survey of dambos in Zimbabwe. Zimbabwe agricultural journal, 81, 129-138.

Whitlow, J.R., 1985. Dambos in Zimbabwe: a review. In: M.F. Thomas and A.S. Goudie, eds. Dambos: small channelless valleys in the tropics. Zeitschrift für Geomorphologie 52. Stuttgart: Borntraeger, $115-146$.

Whitlow, J.R., 1992. Gullying within wetlands in Zimbabwe: an examination of conservation history and spatial patterns. South African geographical journal, 74, 54-62.

Whitlow, J.R., 1994. Gullying within wetlands in Zimbabwe: gully development and factors influencing gully growth. South African geographical journal, 76, 41-48.

Woods, A., 2009. Valuing wetlands for livelihoods as the basis for sustainable management: the SAB approach. Striking a balance, Policy Briefing Note 1. Huddersfield, Yorkshire: Wetland Action and the Centre for Wetlands, Environment and Livelihoods at the University of Huddersfield. 